\title{
Evaluation of Marsh Terraces for Wetland Restoration: A Remote Sensing Approach
}

\author{
Raúl J. Osorio ${ }^{1}$ (D), Anna Linhoss ${ }^{1, *}$ and Padmanava Dash ${ }^{2}$ \\ 1 Department of Agricultural and Biological Engineering, Mississippi State University, Starkville, MS 39762, \\ USA; ro264@msstate.edu \\ 2 Department of Geosciences, Mississippi State University, Starkville, MS 39762, USA; \\ PDASH@geosci.msstate.edu \\ * Correspondence: alinhoss@abe.msstate.edu; Tel.: +1-706-461-3165
}

Received: 13 December 2019; Accepted: 21 January 2020; Published: 24 January 2020

\begin{abstract}
Marsh terracing is a wetland restoration technique that is being implemented in the northern Gulf of Mexico. Marsh terraces are segmented berms of soil built within shallow coastal ponds, designed to increase marsh area and reduce wave energy. Approximately 980 linear $\mathrm{km}$ of marsh terraces have been constructed over almost 30 years in Louisiana and Texas to combat subsidence and sea-level rise; however little research has been conducted to determine their effectiveness. The objective of this study was to assess marsh terrace performance. The change in marsh terrace areas was measured over time through remote sensing. This analysis was conducted using one-meter resolution imagery from the National Agriculture Imagery program (NAIP) from 2003 until 2017 from five Louisiana coastal parishes. Twenty terrace fields of study between 10 and 14 years old were randomly selected within each parish. Results show more predominant deposition (55\%) than erosion $(45 \%)$ in marsh terraces. Terrace fields with high channel density and thereby an external sediment supply show more deposition compared to low channel density fields. This is the first study assessing multiple marsh terrace fields performance. Results are promising, especially considering the current rate of sea level rise and subsidence in Louisiana.
\end{abstract}

Keywords: marsh terracing; marsh restoration; erosion; deposition; change detection; Chenier plain; Deltaic plain; subsidence; sea level rise; coastal wetland

\section{Introduction}

\subsection{Marsh Terracing}

Marsh terracing is a wetland restoration technique consisting of segmented and discontinuous ridges of sediment built in coastal marsh areas [1-3] aligned in a variety of patterns (chevron, squares, circles, checkerboard, etc.). Berm widths range from two to five meters. However, berm length and spacing vary depending on design pattern and location $[4,5]$. The goal of marsh terracing is to reduce wave energy, minimize fetch between ridges, increase marsh area, and possibly reduce shoreline erosion [6,7]. Marsh terraces are usually built in shallow ponds, where natural marshes have been converted to open water [6]. They are constructed at the same elevation of the surrounding marsh to allow periodic inundation of the terraces [3]. Usually, marsh vegetation is planted around the perimeter of the terrace and in the intertidal area to prevent terrace erosion, enhance stability, and ecosystem diversity [7].

Marsh terracing is a relatively new restoration technique. It was first implemented in the U.S. in 1990 at the Sabine National Wildlife Refuge in Cameron Parish, Louisiana [1,8]. Currently, marsh terraces have only been constructed along the northern Gulf of Mexico. If proven effective, 
this restoration technique could be established in other marshes or shallow water regions with similar sediments conditions [2]. In fact, marsh terracing has the same principles of many land reclamation techniques where the main goal is to create new land from coastal shallow areas by drying, pumping water, or raising the elevation of the waterbed in ponds or coastal areas. Land reclamation has been used for a long time in many coastal countries in Europe and Asia [9]. However, the goal of marsh terracing is to create marsh area for wetland recovery purposes and not to convert land for human activities like agriculture, industry, and residential [10].

\subsection{Study Definitions}

For this study, several terms are defined below. A terrace field is defined as an area including a set of terraces following the same pattern or having common attributes (e.g., construction date and design) within the same contiguous water body (inland pond). A terrace field of study is referred to any of the 20 terrace fields analyzed in this study. A terrace field does not include the shorelines or surrounding marsh platforms. Cumulative land change refers to the entire period of land change analyzed for each of the 20 terrace fields of study. Predominant deposition or erosion is defined as the strongest or main long-term geological process quantified throughout the cumulative land change analysis within the terrace field of study. Channels refers to natural or artificial waterways (canals) surrounding or adjacent to the terrace fields of study that may serve as an external supply of water or sediment. High channel density refers to terrace fields of study surrounded or connected by channels. Low channel density refers to either few channels surrounding or connecting terrace fields of study or channels surrounding but not connecting to terrace fields of study, generally blocked by structural marsh management (SMM) such as levees or dikes.

\subsection{Wetland Restoration Techniques}

Many restoration programs have implemented wetland restoration techniques that encourage the creation of new, coastal emergent marsh and potentially reduces sediment erosion and wetland loss [7]. Some examples of these restoration techniques are: breakwater, sediment retention structures, freshwater and sediment diversions, saltwater barriers, vegetative plantings, use of dredged material, and SMM including levees and impoundments [2,3,7,11]. One of the biggest challenges that wetland restoration projects face is assessing success over time and applying new findings to future programs $[12,13]$ and remote sensing technology provides a great potential for change detection analyses and thus very useful in assessing the success of these restoration projects.

\subsection{Remote Sensing in Wetland Analysis}

Remote sensing methods have been used widely for studying wetland in many areas, for example, to assess land use/cover changes and wetland mapping [14]. Marshes are considered a relatively easy type of wetland to identify [15] compared to marsh terraces, which may be more challenging because they are relatively small and narrow pieces of land. Aerial imagery has been successfully used in studies where small areas were analyzed [14]; thus, high-resolution aerial imagery is best for identifying marsh terraces via remote sensing.

Remote sensing methods have been applied successfully across a diversity of projects to identify and assess many aspects of wetlands in Louisiana. For example, Penland et al. (2002) [16] classified coastal land loss between 1932 and 1990 in the Mississippi River Delta Plain using topographic maps and aerial photography. Barras et al. (2003) [17] assessed coastal land loss from 1932-2000 and projected additional losses until 2050 using satellite and aerial images. Couvillion et al. (2011) [18] detected land area changed from 1932 to 2010 in coastal Louisiana employing historical surveys, aerial and satellite data. Oliver-Cabrera \& Wdowinski (2016) [19] detected tidal inundation zones and assessed the interaction between coastal wetlands and tidal currents utilizing Interferometric Synthetic Aperture Radar (InSAR) observations using satellite data. These studies demonstrate the successful application 
of remote sensing methods in coastal Louisiana and the need for implementing wetland restoration projects in this area.

\subsection{Unsupervised Classification and Change Detection Analysis}

Unsupervised classification is a widely used remote sensing technique in wetland land use/cover classification analysis [20,21]. It is a per-pixel method using K-means or ISODATA algorithms to cluster pixels with similar spectral values together. Then the analyst provides information to organize, classify, interpret, and label the clusters into meaningful classes. This method is recommended when field data or previous knowledge of the study area is unavailable [22]. Sometimes clusters do not correspond to the correct class information and accuracy assessments are recommended to verify and correct this issue. Unsupervised classification, also called clustering, is a less time-consuming method than the supervised classification in which the collection of training data is the first and main step [23,24]. According to a review by Ozesmi and Bauer (2002) [25], unsupervised classification is the most commonly applied method to classify land cover in wetland environments.

Once an area has been classified into different land use and land covers, change detection analysis is used to assess change over time in that area. Change detection analysis can be used for understanding relationships between human activities and natural events. Hence, change detection can be used to improve the management of natural resources and to help in decision-making processes [26-28]. Change detection is performed to assess and quantify the historical changes of Earth's features due human or natural phenomena over time with reference to multi-temporal datasets $[26,29,30]$. Different change detection algorithms include: write function memory insertion, multi-date composite image, image algebra (e.g., band or image differencing), post-classification comparison, binary mask applied to date 2, ancillary data source used as date 1, spectral change vector analysis, chi-square transformation, cross-relation, visual on-screen digitization, and knowledge-based vision systems [31]. According to Klemas (2010) [24] image differencing is the most commonly used change detection technique for monitoring wetland changes. Moreover, an important factor to consider when performing change detection analysis is using imagery acquired at the same time or near the same time of the year for every year of analysis to avoid differences related with phenological state, season, and sun angle [24-26].

\subsection{Previous Studies Assessing Marsh Terrace Performance}

Very few projects, remote sensing or otherwise, and a few unpublished technical reports have assessed the performance of marsh terraces regarding erosion and deposition [7]. In fact, there have been more studies on the ecological impacts of marsh terraces [6,32-34] than the success and longevity of marsh terrace physical design. This lack of study on terrace design success has limited the implementation of this technique more widely [7]. The lack of analysis is particularly surprising considering the 980-linear $\mathrm{km}$ of marsh terraces (and 90 terrace fields) that have been constructed [35].

In one of the few studies on marsh terrace design success, Steyer (1993) [8] reported marsh gain at two terraced fields at the Sabine National Wildlife Refuge (NWR) after one year of construction. In this study, a total of 1.47 ha of emergent marsh were mainly present on the terrace footprints. Two years post terrace construction, new vegetation covered adjacent areas of the terrace footprints resulting in 6.8 ha of new marsh. In another study of marsh terrace design success, Good et al. (2005) [36] assessed change in land area of two terrace fields at the same Sabine NWR using GIS methods and aerial photography. This study documented a 4.71 ha (18\%) total increase of emergent marsh within the terrace field and adjacent areas of non-terraced islands and shorelines over a period of ten years.

Castellanos and Aucoin (2004) [37] compared aerial photography of one recently constructed terrace field and a reference site with 2 years post-construction imagery in the Little Vermilion Bay. They documented $2.1 \mathrm{ha}(7 \%)$ land loss of two terrace fields and surrounding marsh. Also, they reported a mudflat increase of 80.7 ha in the terrace field and an increase of 4.51 ha in the reference site. Land loss was mainly attributed to sacrificial terraces built in the southern area of the terrace field. 
Thibodeaux et al. (2009) [38] monitored two terrace fields three years post-construction. They reported a decrease of $16 \%$ in emergent vegetation outside the terrace footprints in the Pecan Island restoration terrace field in southwest Louisiana compared with a nearby reference site that decreased by $9 \%$ in emergent vegetation. Miller et al. (2011) [39] performed a land change analysis from 2004-2007 for eastern Little Vermilion Bay and Little White Lake terrace sites in south central Louisiana. This analysis showed land gain of 7.3 ha and 2.8 ha, respectively along terrace edges in both terrace fields. While these results are promising they mostly present short-term findings from five terrace fields.

\subsection{Study Objectives}

In order to broadly assess the efficacy of marsh terraces, a more comprehensive review of terrace performance in multiple sites over multiple years is needed. Therefore, the objective of this study is to assess the change in marsh terrace area over time, using classification of high-resolution aerial imagery and subsequent change detection analysis. Questions that will be addressed in this research include: (1) how do the terraces perform over time and space and (2) which marsh terrace design factors are related to terrace performance?

\section{Materials and Methods}

\subsection{Data and Study Area}

Marsh terrace change over time was analyzed by two databases: (1) a marsh terrace geodatabase in ArcGIS platform as shapefiles created by Ducks Unlimited (DU) [35] and (2) approximately 120 aerial images from the National Agriculture Imagery Program (NAIP) [40] from five parishes in coastal Louisiana from 2003-2017. Due to limitations in NAIP imagery and computational time, all terrace fields were not assessed. Three criteria were used to select a subset of terrace fields which includes terrace age, geopolitical location, and imagery cloud cover. These criteria are described below.

First, terrace fields of study that were at least ten years old (built between 2003 and 2007) were selected. Ten years of aerial imagery provided a time lapse, which could be considered as a sufficient time-period to evaluate moderately long-term terrace performance. Terraces built before 2003 were not included in the analyses because NAIP imagery was only available since 2003.

Second, specific fields of study were further randomly selected based on their geopolitical location. Coastal Louisiana is politically divided in eight parishes and geomorphologically divided in two regions, the Chenier Plain in the southwest and the Deltaic Plain of the Mississippi River in the southeast (Figure 1). Both regions differ in geologic processes, coastal morphology, and hydrological characteristics [6]. Furthermore, the rates of subsidence and relative sea-level rise are both greater in the Deltaic region (11.2 mm per year and $13.2 \pm 8.8 \mathrm{~mm}$ per year, respectively) than in the Chenier Plain (7.5 mm per year and $9.5 \pm 6.3 \mathrm{~mm}$ per year, respectively [41].

Third, after the terrace fields were screened based on the first two selection criteria, cloud free images were visually selected for unsupervised classification. The NAIP imagery with less than 10\% cloud cover per quarter quad tile were selected [42].

According to the DU dataset [35], approximately 90 terrace fields have been built from 1990 until 2017 in Louisiana and Texas. Sixty out of these 90 terrace fields were built between 2003 and 2017, including 50 in the Chenier region and ten in Deltaic region. Most of the terrace fields were built in the Chenier Plain due to more suitable construction sites and substrates characteristics [43]. Based on the selection criteria, a total of 20 marsh terrace fields in coastal Louisiana were randomly selected. This resulted in six terrace study fields located in Cameron Parish, nine in Vermilion, one in Iberia, two in St. Mary, and two in Terrebonne. Thus, a total of seventeen terrace fields were from the Chenier region and three terrace fields were from the Deltaic region (Figure 1). 

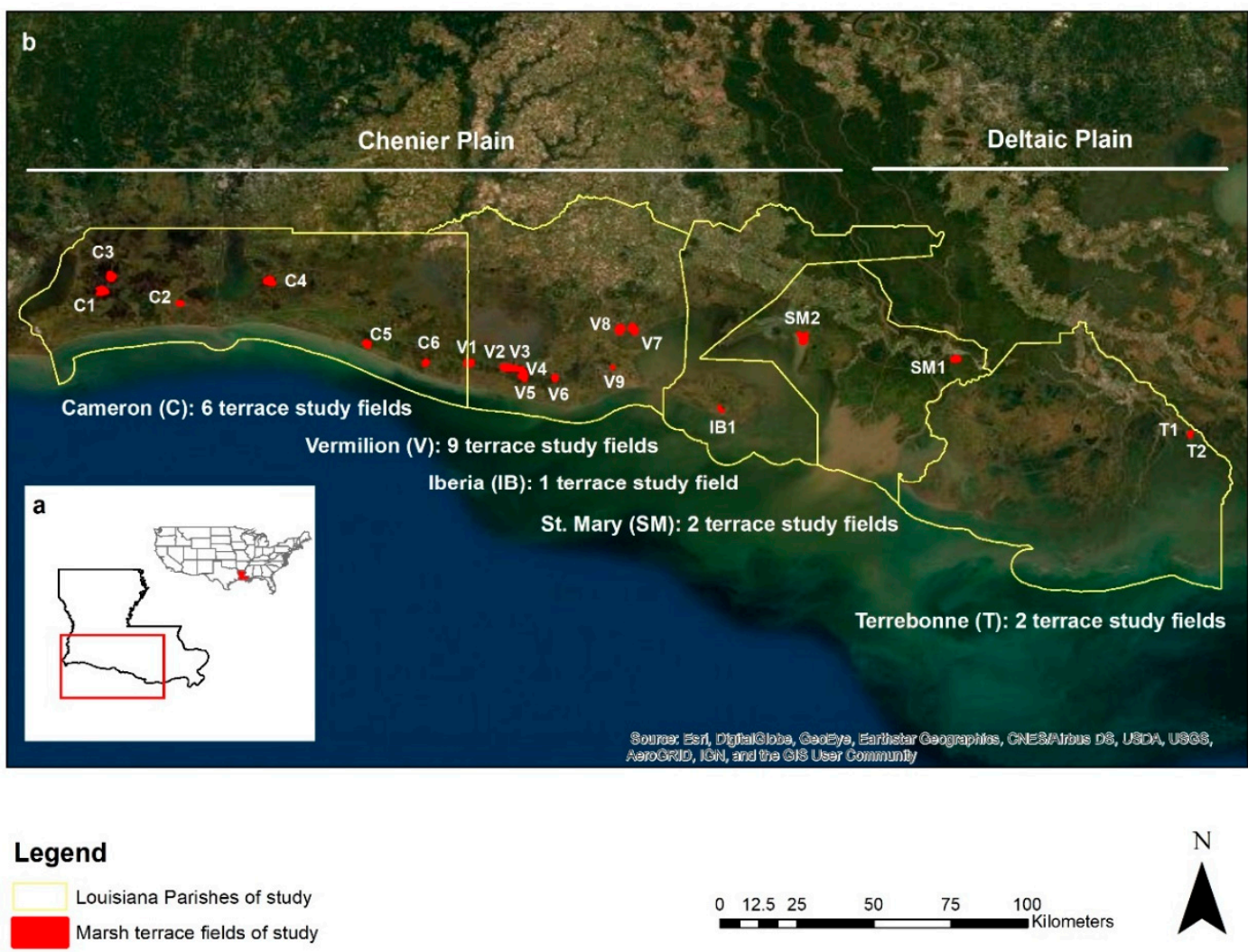

Figure 1. (a) Coastal Louisiana. U.S.; (b) Marsh terrace fields of study selected to assess performance over time in the Chenier Plain and Deltaic Plain Region in Coastal Louisiana.

NAIP aerial imagery has one-meter spatial resolution with three bands in the red, green, and blue wavelength region [42]. This imagery was used for three main reasons. First, it is freely available. Second, the one-meter spatial resolution is appropriate for this study. Third, NAIP imagery is already preprocessed by the federal program and is available in digital ortho-quarter quad tiles (DOQQs) or compressed in county mosaics (CCM) [42]. The imagery is already geometrically corrected to UTM coordinate system and are ortho-rectified for planimetric accuracy [44]. The remote sensing method applied standard photogrammetric techniques to the NAIP imagery.

Water level data was downloaded from the Louisiana's Coastwide Reference Monitoring system (CRMS) website [45] matching the time of imagery acquisition. This was done to identify potentially misleading results in the marsh terrace change in area due to water level fluctuations. It is important to mention that in some of the marsh terrace fields in the Chenier Plain, water levels are controlled by water control structures, which are managed by property owners. Structural marsh management (SMM) has been predominant in the Chenier Plain [46] since the middle of the 1950's, with the purpose of reducing saltwater intrusion, control water level, and reducing open water areas [47,48]. SMM techniques include levees, impoundments, and water control structures [49].

\subsection{Data Analysis}

ArcMap 10.5.1 [50] was used to create feature classes of the terrace fields of study. Polygons were drawn for delineating each of the terrace fields without including the shoreline or surrounding marsh platform. Imagery subsetting and remote sensing unsupervised classification were performed using ERDAS IMAGINE Software [51]. Imagery subsetting was done using the terrace field polygons created in ArcMap and the NAIP imagery from Louisiana Parishes. As a result, a mask was created for each terrace field of study. The Iterative Self Organizing Data (ISODATA) algorithm [23] was used to derive information clusters based on a previous study [32]. This was done with the purpose of classifying 
the aerial imagery into land and water categories. A minimum distance algorithm was used in this study. Marsh terrace fields of study, where floating aquatic vegetation or submerged aquatic vegetation (SAV) were present in the aerial imagery, were classified using three categories (water, land, aquatic vegetation) instead of just 2 (water and land). Those fields were classified with utmost care by creating more classes after properly recoding them following suggestions given by Couvillion et al. (2011) [18]. This was done to achieve higher accuracy and to avoid misclassification.

ArcMap 10.5.1 and PythonWin 2.7.13 [52] were used to edit classified rasters, add fields, generate new categories in the rasters, create and reclassify difference maps, and generate land change detection maps for each terrace field of study. Post-classification image differencing was performed as change detection methods in this study. A class score was given to each classified land cover class ( 1 for water, 2 for land). Using the new class score value field, the classified image from the first chronological year of analysis or the year when the terrace was built (i.e., 2003) was subtracted from the other classified images (i.e., 2005, 2007 ... 2017), one by one. This analysis shows cumulative change over time for each image after the first image (i.e., 2003-2005, 2003-2007 .. 2003-2017). This post-classification difference map process separated the classified raster pixels in three categories: erosion, deposition and no change. Post-classification image differentiation was performed to obtain the cumulative change in the erosion and deposition of the terrace fields of study.

Accuracy assessments were conducted from classified imagery. A confusion matrix [53,54] was computed using randomly chosen accuracy assessment points. These random points were created using an equalized stratified random sampling strategy so that each class had the same number of points. A table was created where each random point had a record for ground truth and for the classified image value. The ground truth field was updated by visually comparing the classified value with the equivalent area in Google Earth Pro [55] and NAIP imagery. The confusion matrix calculated errors of omission and commission; and finally, a kappa index was derived denoting agreement and an overall accuracy. Kappa index ranges from 0 to 1 . Coefficients higher than 0.7 are considered acceptable and those equal or lower than 0.4 indicate a low correlation between the classified image and the reference image of comparison [56,57]. This was conducted based on the importance of having high classification accuracy in the images to detect real changes and to avoid misleading classification results [25].

The change detection analyses were performed every two/three-years depending on the terrace field of study. Due to imagery limitations, the same years could not be analyzed for every terrace field of study. If the desired imagery had cloud cover or if it was not available, the previous or following year was assessed. Spatial measurements such as land change percentages and area in hectares, and accuracy assessments were calculated. Similar to the Good et al. (2005) [36] study, inferential statistics were not applied because treatment replication (between terrace fields and over time) is impractical [58].

The results from these analyses, predominantly erosional or depositional terrace fields, were related to the following independent terrace design factors: terrace location (Chenier or Deltaic region), terrace shape (linear, chevron, rectangular or other), terrace size (small $<40$ hectares, big $>40$ hectares), alignment of the terraces (north, south, east, west and diagonal), and finally a visual identification to determine if the terrace fields were surrounded or connected by channels, levees, or open water.

Due to computational time, the number of terrace study fields was limited to 20. This, in addition to the fact that treatment replications are impractical, made statistical analyses unfeasible. As such, results from this study should be considered descriptive rather than quantitative.

\section{Results}

Overall, in the marsh terrace fields of study, performance over time showed more predominant deposition (55\%) than erosion (45\%). A confusion matrix, summarizing the accuracy assessment results for the classified imagery, is shown in Table 1. The mean Kappa index of agreement was 0.86 $(86 \%)$ with a standard deviation of 0.11 . The Kappa coefficient is considered acceptable for imagery 
classification [56,57]. Therefore, there is a strong agreement and good accuracy between the classified imagery and reference imagery. The mean and standard deviation of the errors of omission and commission for each class of the classified imagery are also shown in Table 1.

Table 1. Confusion Matrix showing the accuracy assessment results for the classified imagery. The values correspond to the mean \pm the standard deviation of the classified imagery.

\begin{tabular}{lccccc}
\hline & Water & Land & Total & Errors of Commission & Kappa \\
\hline Water & $28.85 \pm 1.73$ & $0.99 \pm 1.29$ & $30 \pm 0$ & $0.97 \pm 0.04$ & \\
Land & $2.85 \pm 3.11$ & $26.69 \pm 3.91$ & $30 \pm 0$ & $0.89 \pm 0.13$ & \\
Total & $31.82 \pm 3.77$ & $27.92 \pm 4.03$ & $60 \pm 0$ & & \\
Errors of omission & $0.91 \pm 0.08$ & $0.96 \pm 0.05$ & & $0.93 \pm 0.06$ & \\
Total & & & & & $0.86 \pm 0.11$ \\
\hline
\end{tabular}

Figure 2 shows an example of an analyzed marsh terrace field of study (C3), located in Cameron Parish, that demonstrated predominant deposition. This terrace field was constructed in 2006. In this example, overall cumulative terrace deposition was more predominant than cumulative erosion, in other words deposition is higher than erosion in each period of analysis. This trend was consistent across years (Table 2; Figure 3). In this example, deposition mostly occurred in the southern portion of the terrace field of study (Figure 2e).
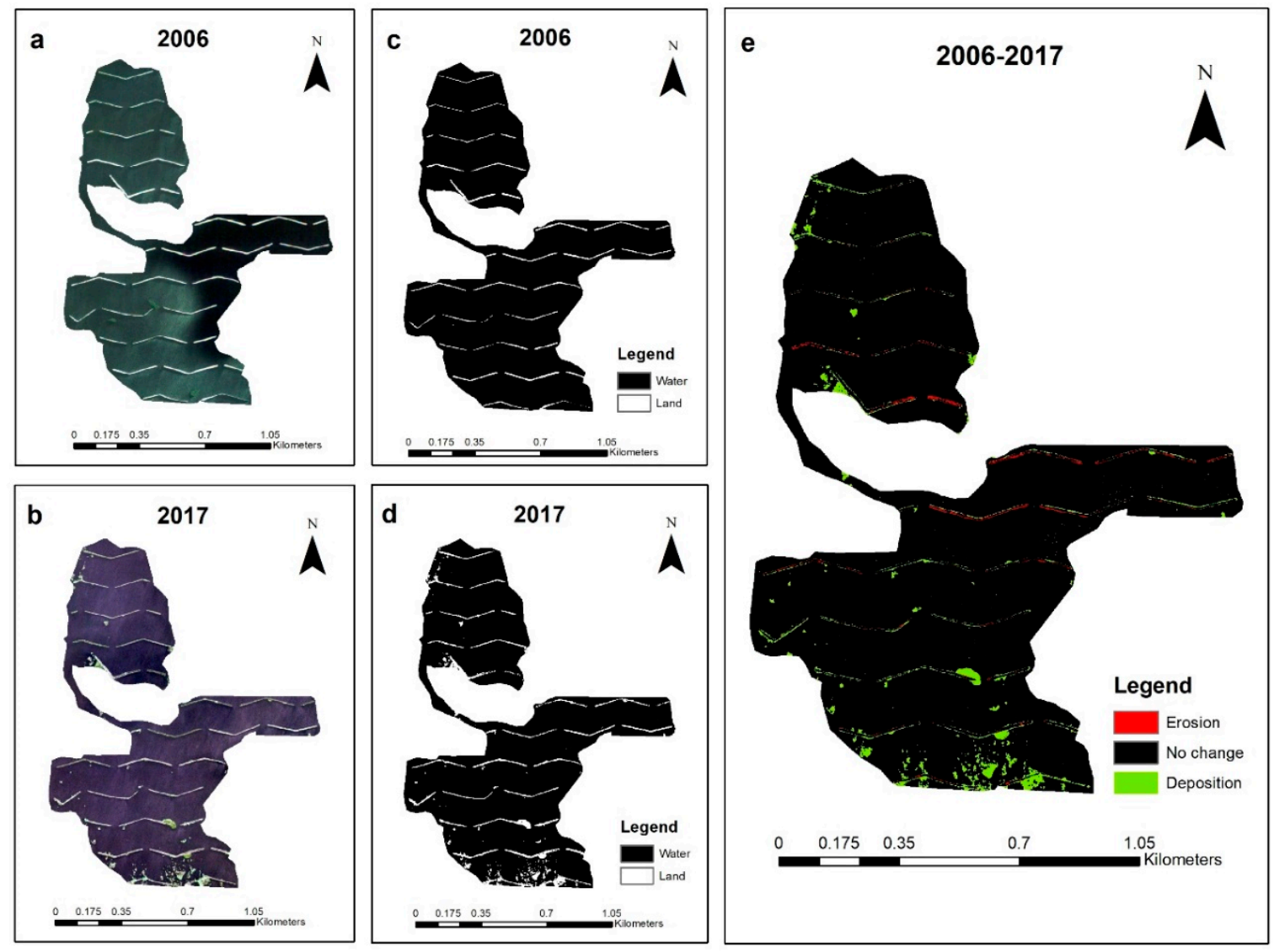

Figure 2. Analysis of a terrace field (C3) at Cameron Parish, LA. (a) Marsh terrace National Agriculture Imagery program (NAIP) imagery from 2006 showing the terraces recently built (where the white color is recently constructed and unvegetated terraces); (b) Marsh terrace NAIP imagery from 2017 showing the vegetated terraces (green color) after 11 years of establishment; (c,d) Marsh terrace land/water classified imagery from 2006 and 2017 respectively, where the white color represents the terraces and black color represents water within the polygon of analysis; (e) Change detection map from 2006-2017 where red color represents erosion, black is no change, and light green represent deposition. 
Table 2. Cumulative land change $\%$ and area (ha) of C3 marsh terrace field at Cameron Parish LA.

\begin{tabular}{lcccccccccc}
\hline & \multicolumn{2}{c}{$\mathbf{2 0 0 6}-\mathbf{2 0 0 7}$} & \multicolumn{2}{c}{$\mathbf{2 0 0 6 - 2 0 1 0}$} & \multicolumn{2}{c}{$\mathbf{2 0 0 6 - 2 0 1 3}$} & \multicolumn{2}{c}{$\mathbf{2 0 0 6 - 2 0 1 5}$} & \multicolumn{2}{c}{$\mathbf{2 0 0 6 - 2 0 1 7}$} \\
\hline & $\mathbf{\%}$ & ha & $\mathbf{\%}$ & ha & $\mathbf{\%}$ & ha & $\mathbf{\%}$ & ha & $\mathbf{\%}$ & ha \\
\hline Erosion & 0.2 & 0.2 & 1.2 & 1.2 & 0.4 & 0.4 & 0.7 & 0.7 & 0.6 & 0.6 \\
No Change & 96.9 & 106.5 & 96.6 & 106.1 & 96.6 & 106.1 & 95.2 & 104.6 & 96.4 & 105.9 \\
Deposition & 2.9 & 3.1 & 2.3 & 2.5 & 3.1 & 3.3 & 4.1 & 4.5 & 3.1 & 3.3 \\
\hline
\end{tabular}

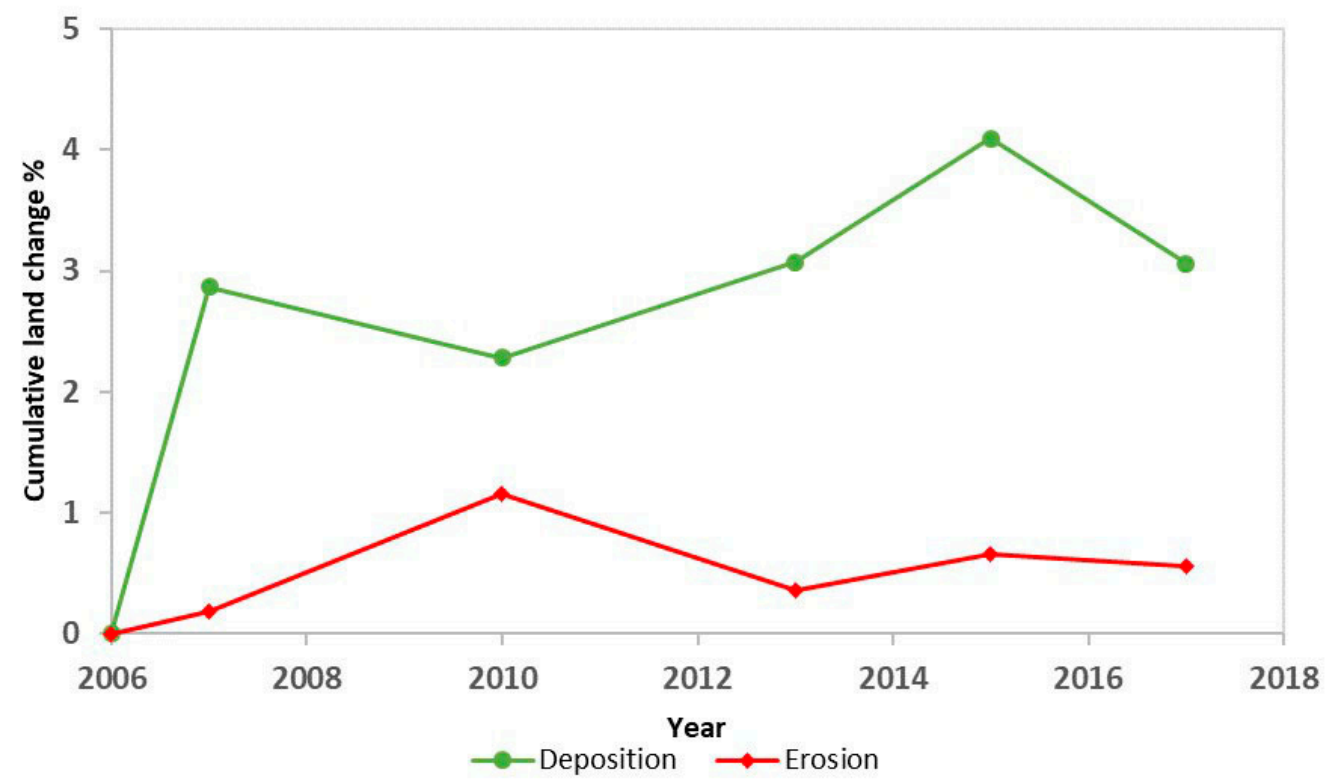

Figure 3. Trend graph showing cumulative marsh terrace performance from 2006-2017 of C3 terrace field of study.

The analysis described for terrace C 3 was conducted for each of the remaining 19 terrace fields of study. The data for each of these analyses is too cumbersome to present in this publication. Thus, summary statistics are presented in Table 3.

Terrace fields of study showed predominant deposition in $11(55 \%)$ terrace fields; eight of these depositional sites $(47 \%)$ were located in the Chenier region, and three $(100 \%)$ were located in the Deltaic region. Predominant erosion was found in nine (45\%) of the terrace fields. All of these erosional sites (53\%) were located in the Chenier region (Table 3). In most cases, terrace fields that had high density of adjacent channels or relate to channels, thereby an external sediment source, displayed more predominant deposition (11) compared to terraces surrounded with a low density of channels (six; Table 3).

In southwestern Louisiana, out of the six terrace fields of study in Cameron Parish, predominant deposition occurred in four and predominant erosion occurred in two terrace fields. Vermilion Parish had the highest number of predominant eroded terrace fields of study with a total of nine fields. In this parish, only three showed predominant deposition and the remaining six showed predominant erosion. In Iberia Parish the single marsh terrace field that was analyzed showed predominant erosion over time. Both terrace fields of study in St. Mary showed predominant deposition. Finally, the two terrace fields of study located in Terrebonne showed predominant deposition. The results mentioned above are also spatially depicted in Figure 4. 
Table 3. Marsh terraces fields of study design factors and performance. Alignment definitions: west to east terrace alignment (W/E), north to south terrace alignment (N/S), arbitrary refers to a terrace alignment following different directions within a terrace field of study. Channel density definitions: high refers to channels surrounding or connecting with the terrace field of study; low refers to either few channels surrounding or connecting with the terrace field of study or presence of channels not connected with the terrace field of study blocked by levees or dikes. Performance refers to either predominant deposition or erosion in a field of study.

\begin{tabular}{|c|c|c|c|c|c|c|c|c|}
\hline Terrace & Parish & $\begin{array}{l}\text { Geological } \\
\text { Region }\end{array}$ & Shape & Alignment & $\begin{array}{c}\text { Area } \\
\text { (Hectares) }\end{array}$ & $\begin{array}{l}\text { Channel } \\
\text { Density }\end{array}$ & Levees & Performance \\
\hline $\mathrm{C} 1$ & Cameron & Chenier & chevron & $\mathrm{W} / \mathrm{E}$ & 322.81 & high & yes & deposition \\
\hline $\mathrm{C} 2$ & Cameron & Chenier & linear & $\mathrm{W} / \mathrm{E}$ & 12.61 & low & yes & erosion \\
\hline $\mathrm{C} 3$ & Cameron & Chenier & chevron & $\mathrm{W} / \mathrm{E}$ & 109.54 & high & yes & deposition \\
\hline $\mathrm{C} 4$ & Cameron & Chenier & chevron & diagonal & 142.06 & high & no & deposition \\
\hline C5 & Cameron & Chenier & rectangular & diagonal & 54.82 & high & yes & deposition \\
\hline C6 & Cameron & Chenier & linear & diagonal & 11.78 & high & no & erosion \\
\hline V1 & Vermilion & Chenier & chevron & W/E & 98.58 & high & yes & deposition \\
\hline $\mathrm{V} 2$ & Vermilion & Chenier & rectangular & $\mathrm{W} / \mathrm{E}$ & 312.69 & low & yes & erosion \\
\hline V3 & Vermilion & Chenier & rectangular & N/S & 218.83 & low & yes & erosion \\
\hline V4 & Vermilion & Chenier & chevron & diagonal & 279.27 & low & yes & erosion \\
\hline V5 & Vermilion & Chenier & linear & arbitrary & 25.03 & high & yes & deposition \\
\hline V6 & Vermilion & Chenier & chevron & $\mathrm{W} / \mathrm{E}$ & 38.26 & low & no & erosion \\
\hline V7 & Vermilion & Chenier & linear & arbitrary & 169.11 & high & no & deposition \\
\hline V8 & Vermilion & Chenier & linear & arbitrary & 107.88 & low & no & erosion \\
\hline V9 & Vermilion & Chenier & linear & diagonal & 7.84 & high & no & erosion \\
\hline IB1 & Iberia & Chenier & linear & N/S;W/E & 29.53 & high & no & erosion \\
\hline SM1 & St. Mary & Deltaic & chevron & diagonal & 56.38 & high & yes & deposition \\
\hline SM2 & St. Mary & Chenier & linear & arbitrary & 430.23 & high & no & deposition \\
\hline $\mathrm{T} 1$ & Terrebonne & Deltaic & linear & $\mathrm{W} / \mathrm{E}$ & 19.75 & high & no & deposition \\
\hline $\mathrm{T} 2$ & Terrebonne & Deltaic & linear & $\mathrm{W} / \mathrm{E}$ & 22.95 & high & no & deposition \\
\hline
\end{tabular}

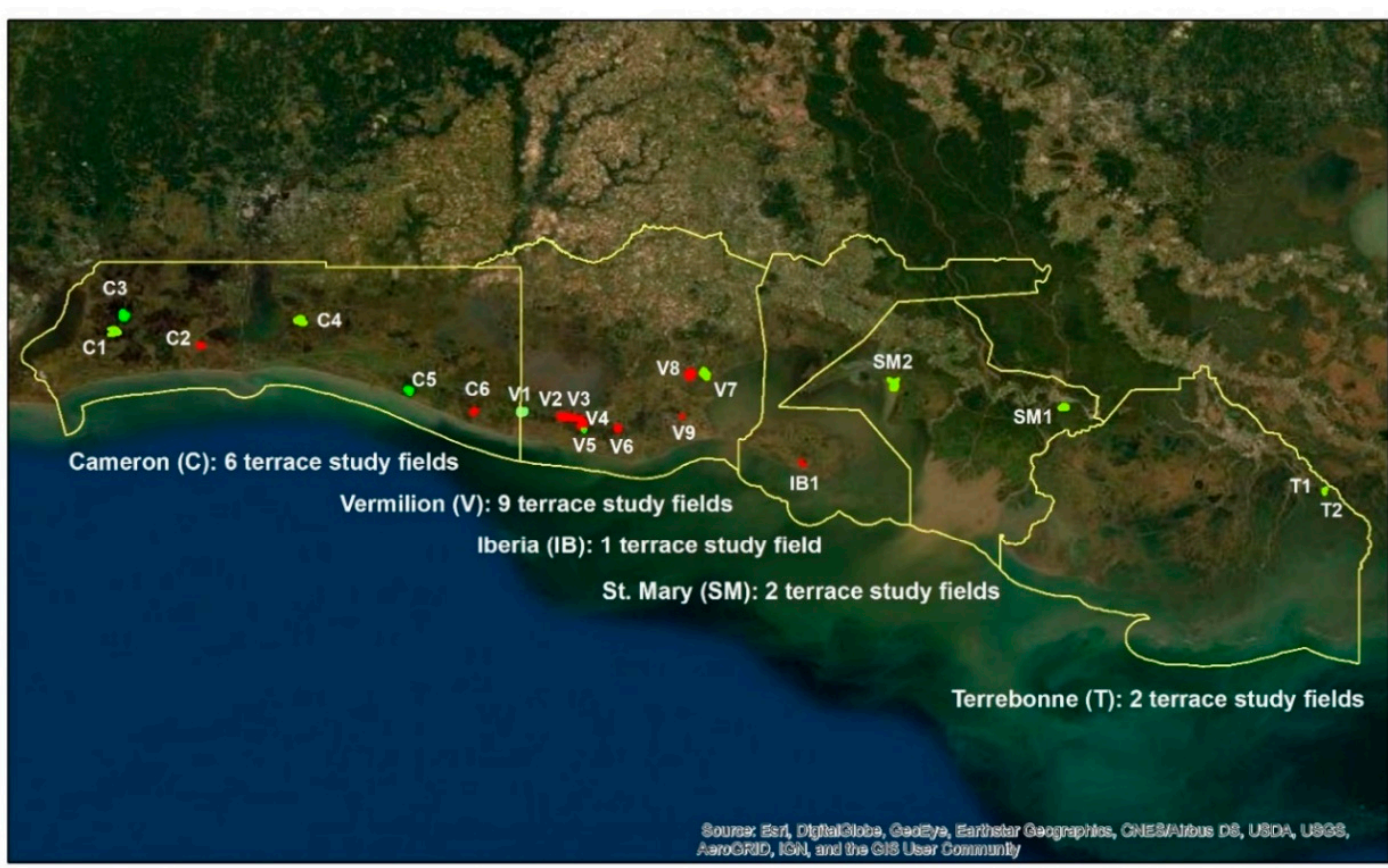

\section{Legend}

Louisiana parishes of study

Predominant deposition terrace fields of study

Predominant erosion terrace fields of study
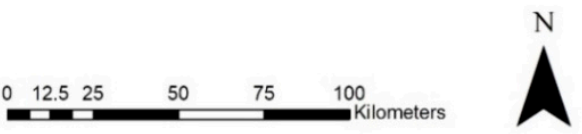

Figure 4. Marsh terrace fields of study performance over time in the Chenier Plain and Deltaic Plain Region in Coastal Louisiana. T1 and T2 are overlapping. 
Figures 5 and 6 show trends of all the terrace fields' cumulative land change percentage over time. In most cases, trend lines do not cross, which means marsh terrace fields of study are either consistently erosional (seven fields of study, 35\%) or depositional (seven fields of study, 35\%).

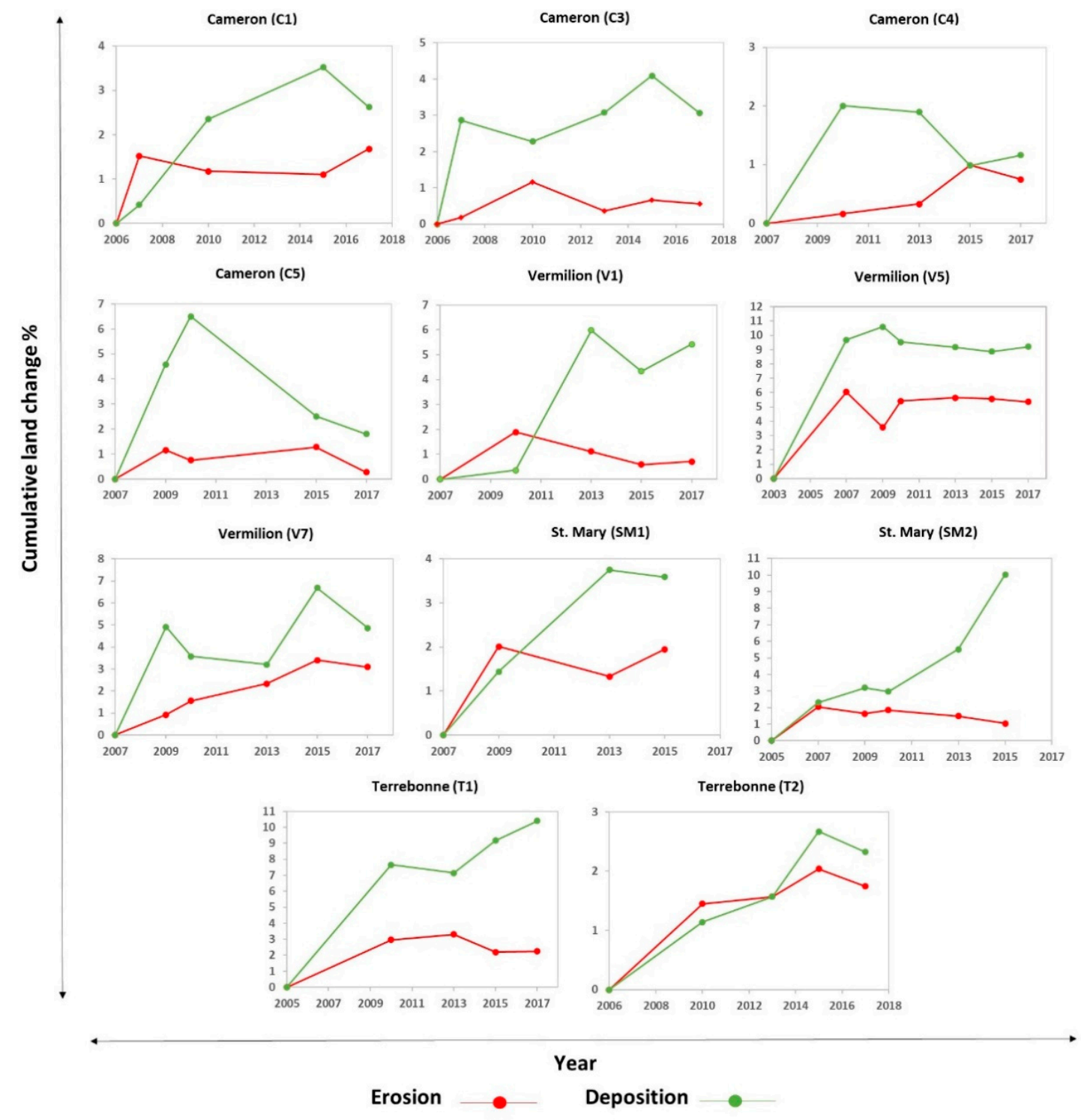

Figure 5. Land change trends of marsh terrace fields showing predominant deposition over time. 


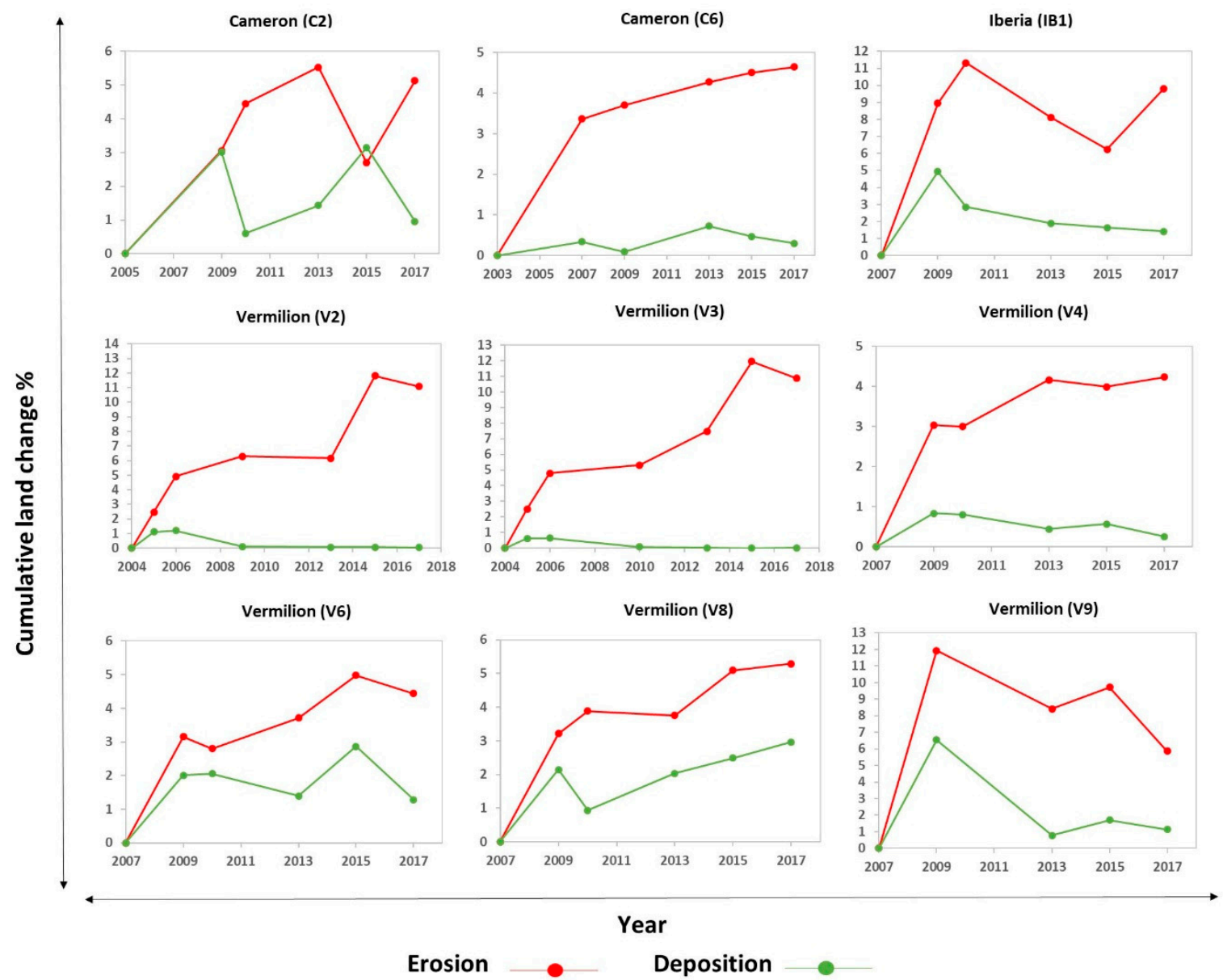

Figure 6. Land change trends of marsh terrace fields showing predominant erosion over time.

One potential issue in this study was the fact that imagery was taken under varying hydrological and tidal regimes. This presented the threat of results reflecting changes in water elevation and not land loss. However, $70 \%$ of the results show consistent deposition or erosion. This consistency supports our conclusion that the change analysis represents changes in terraces area and not differences in water elevation. This conclusion was also supported by observing water level data at the date and time of the NAIP aerial imagery acquisition. In general water level fluctuated between 30 and $60 \mathrm{~cm}$ in terrace fields of study. Bolduc and Afton (2005) [49] also mentioned that water levels in ponds of managed marshes are between 29 and $39 \mathrm{~cm}$ on average. Imagery was observed for years with high $(>60 \mathrm{~cm})$ and low $(<30 \mathrm{~cm})$ water levels in the terrace fields of study. The absence of a halo effect surrounding the terraces and terraces design features, especially the slope and vegetation in the edges, confirmed that differences in water level did not affect the area of analysis.

The analyses from the average cumulative land change by year of marsh terraces (Figure 7) showed that the average highest peak of marsh terraces erosion occurred in $2006(-5 \%), 2009(4 \%)$ and $2017(-4 \%)$. The highest peaks of deposition occurred in 2007 (3\%), $2009(3.5 \%), 2015(3.7 \%)$ and $2017(3 \%)$. 


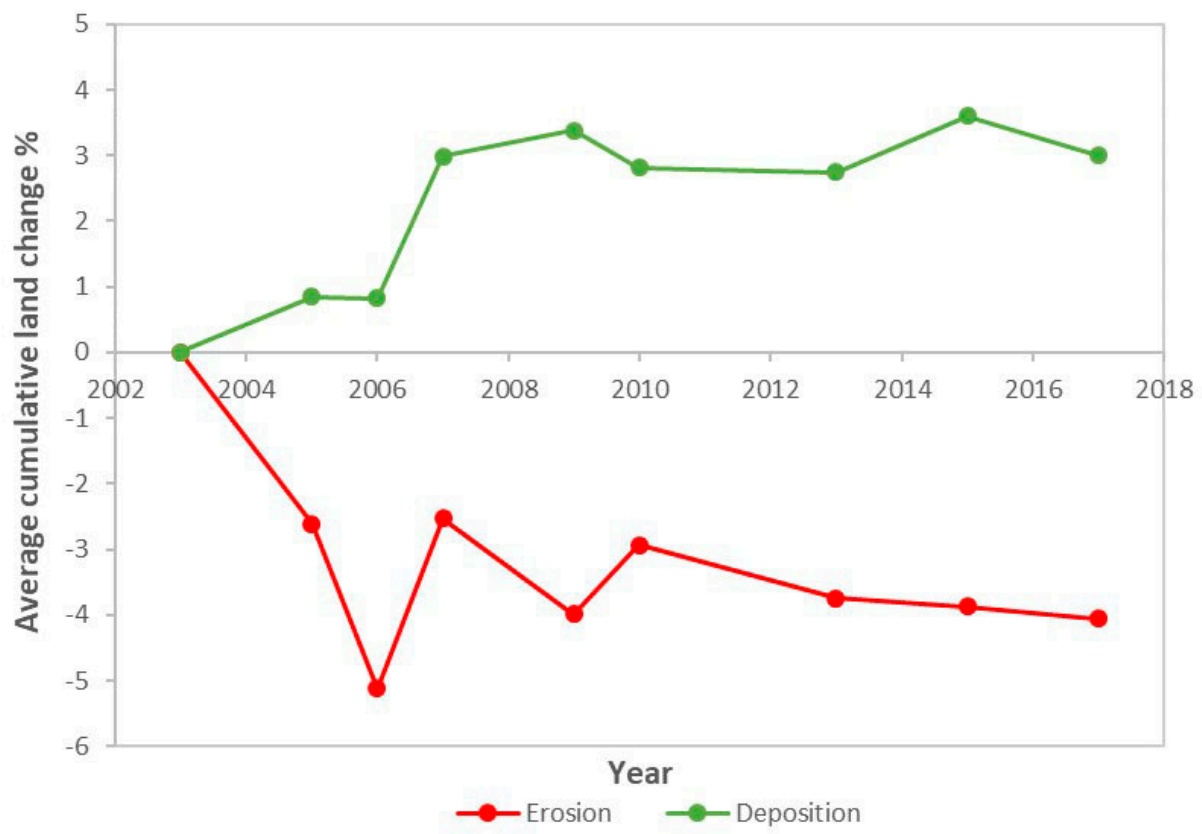

Figure 7. Average cumulative marsh terraces land change from all the sites by year.

Two tentative relationships were found between the terrace field performance (eroded and deposited) and independent terrace design factors (geomorphological location, shape, alignment, size, levees, adjacent to a channel): (1) terrace location (Chenier or Deltaic region) and (2) whether or not terrace fields were surrounded by channels and SMM (levees).

\section{Discussion}

\subsection{Marsh Terrace Performance and Geomorphological Location}

Findings from this study show that 11 out of 20 marsh terrace fields of study resulted in overall deposition. This success rate is particularly important within the context of local subsidence (5-10 $\mathrm{mm}$ per year) [41,59-61] and sea level rise (12 $\pm 8 \mathrm{~mm}$ per year) [41] in coastal Louisiana. The fact that there is over $50 \%$ deposition in the terrace fields of study under both sea-level rise and subsidence indicates a measure of success.

Previous studies have reported that the Geomorphic regions (Chenier and Deltaic) have an erosional and depositional trend based on their sediment supply and on the geological processes at work in those regions [41,62]. The Chenier Plain is newer and formational with its central part still erosional [62]. The erosional nature of the Chenier Plain could be related to mixed performance results showing predominant terrace erosion in nine out of 17 terrace fields of study located in the Chenier region. The Deltaic region is older [63] with vertical accretion and surface elevation (mean elevation of salt marshes surfaces) rates greater than that of the Chenier Plain. These rates show a decreasing trend from east (Deltaic region) to west (Chenier region) in coastal Louisiana [41]. The three terrace study fields showed predominant deposition in the Deltaic Plain. Although the number of study sites in the Deltaic region were limited and three study sites are not enough to make conclusions regarding success rates related to geomorphic processes, our findings follow the erosional and depositional trends of the geomorphic regions explained above. Greater deposition rates were found in the Deltaic than in the Chenier Plain.

On the other hand, sea level rise and subsidence rates in the Deltaic region are greater than that of the Chenier Plain [41,64]. Yet, all three sites in the Deltaic region are depositional, while there are mixed results in the Chenier region. However, all three sites in the Deltaic region were also connected 
to or surrounded by channels with external sediment supply, which may have potentially affected the interpretation of these results.

More research is needed to understand how marsh terraces perform relative to the geomorphologic region. Finding suitable sites for marsh terrace construction is difficult in the Deltaic region because the soils are less cohesive (organic soils) [65] than soils in the Chenier Plain which is composed of mudflats (organic, silty clay soils) [43,62]. Additionally, most Louisiana marshes have thick organic soils with low shear strengths and low elevation which make marshes more vulnerable to wave and wind-driven erosion than other marshes in the world [66].

\subsection{Marsh Terrace Performance Related to Channels and Levees}

An important finding from the relationship between marsh terrace design factors and terrace longevity was related to whether or not the terraces were surrounded by channels. Fourteen of the 20 sites had a high density of channels connected or adjacent to the terrace fields of study. All 11 depositional sites had a high density of adjacent or connecting channels. This indicates that an external sediment source promotes predominant deposition in marsh terraces. Similarly, Good et al. (2005) [36] inferred that differences in marsh growth between terraced fields are related to amounts of sediment entering the ponds. Conversely, Day et al. (2000) [67] stated that wetlands with a high density of channels are generally related to high rates of land loss, among other factors.

Predominant erosion was found in nine terrace sites that were all located in the Chenier region. In the Chenier Plain there is a particularly high concentration of levees [46]. These levees are used as a structural marsh management (SMM) technique. SMM techniques alter sediments' biological and physical characteristics, decreasing sediment supply to the marsh fields $[10,68]$ and reducing marsh deposition $[69,70]$. So, in this area, even if there are adjacent or channels with high channel density connected to the marsh fields, these channels may be sediment starved and not able to contribute sediment to the terrace fields [49] because levees restrict tidal flows. This anthropogenic factor could be a reason of predominant terrace erosion in the Chenier region.

Sometimes marsh terraces are combined with other restoration techniques such as river diversions [7]. Marsh terraces were included in the output embayment of a river crevasse project in Plaquemines Parish Louisiana. Terraces were incorporated with the purpose to capture and settle sediment carried by the Mississippi River. The results were promising with five years after terrace construction emergent marsh increased by 3.2 ha (1\%) within the terrace field boundaries [71]. Therefore, future sediment diversion plans in the Deltaic Plain [72] may considerably contribute to the amount of sediment entering the terrace fields, enhancing deposition and potentially reducing land erosion in the Chenier Plain [63]. Furthermore, sediment diversion plans should incorporate marsh terracing to encourage the deposition of sediments in strategic locations. The present study agrees with Day et al. (2000) [67] who mentioned that various restoration projects (e.g., marsh terracing) can be implemented to reduce land loss, but ultimately riverine input or an external source of sediment loading is necessary for creating new land.

\subsection{Marsh Terrace Performance and Storm Events}

Storm surge can inundate inland marshes, alter the sediment transport processes, and can act as an important agent of wetland loss [62]. Storms can either be land destructive (erosional) or constructive (depositional) [73]. The average cumulative highest peaks of erosion in the terrace fields of study were in 2005-2006 and 2007-2009. It has already been shown that in 2005 category 5 hurricanes Katrina and Rita and in 2008 category 4 hurricanes Gustav and Ike contributed to land loss [65,73]. Our results, showing increased terrace erosion during these time periods, corroborate findings that these storms were erosional. These results also agree with previous studies $[18,74,75]$ that mentioned episodic events like strong storms (e.g., greater than category three hurricanes) contributed significantly to high rates of land loss in the northern coast of the Gulf of Mexico. 
Tweel and Turner (2012) [76] reported that hurricanes are a potential driver for land loss but they also demonstrated that hurricanes Katrina, Rita, Gustav, and Ike deposited great amounts of sediment in the northern Gulf of Mexico. While overall erosion between all terrace fields of study peaked during the periods including storm events, deposition was also observed within the marsh terraces fields of study in the same time periods. Possibly the sediment source for terrace deposition was from the sediment removed from other land features surrounding the marsh terrace field or from sediment supplied by the storm surge. In fact, according to Draut et al. (2005) [77] and Jankowski et al. (2017) [41], energetic events like storms and cold fronts are factors that contribute to wetland deposition in coastal Louisiana. However, the average cumulative marsh terrace deposition observed in this study was not enough to offset the average cumulative marsh terrace erosion in 2006 and 2009.

\section{Conclusions}

This study assessed marsh terrace performance of 20 terrace fields in coastal Louisiana using a remote sensing approach. The change in marsh terrace areas was measured over time using NAIP imagery from 2003 until 2017 from five Louisiana coastal parishes. Marsh terrace performance over time shows more predominant deposition than erosion in the 20 terrace fields of study, even in the face of subsidence and sea level rise. Their longevity within a 10-14-year time period effectively achieved one of the terrace restoration goals, which is marsh creation. A relationship was found between geomorphological area, sediment supply, and adjacent or connecting channels with terrace fields of study performance. High density of channels surrounding or adjacent to the terrace fields, and external source of sediment loading are likely important drivers encouraging terrace deposition. However, further analysis is necessary to understand the reasons for differences in performance of these terraces. In the future, these results will be related to environmental factors (sediment type, sediment load, soil strength, salinity, terrace location in relation to wave energy, etc.) and other drivers (wind and wave energy) that might play an important role for the success of this restoration technique. This will help restoration planners select optimal sites and designs for marsh terrace implementation.

This study is particularly important given the lack of previous research on marsh terrace effectiveness and longevity over time in multiple sites and over multiple years. We expect that this study will encourage new research assessing this technique's effectiveness and identifying the most effective terrace designs. This will allow restoration agencies to address one of the biggest challenges in wetlands restoration projects, which is applying lessons learned in previous projects by assessing the results of previously implemented techniques.

Author Contributions: Conceptualization, R.J.O. and A.L.; methodology, P.D. and R.J.O.; software, P.D. and R.J.O.; validation, P.D. and A.L.; formal analysis, R.J.O.; investigation, R.J.O. and A.L.; resources, P.D.; writing一original draft preparation, R.J.O.; writing-review and editing, A.L. and P.D.; visualization, R.J.O., A.L., and P.D.; supervision, A.L.; project administration, A.L. and R.J.O.; funding acquisition, A.L. All authors have read and agreed to the published version of the manuscript.

Funding: This research was funded by the National Academies of Sciences, Engineering and Medicine. Gulf Research Program, grant number 2000008944. This material is also based upon work supported by the National Institute of Food and Agriculture, U.S. Department of Agriculture, under Project No. W4188.

Acknowledgments: The authors would like to thank other members of the marsh terracing project: Michael Brasher from Ducks Unlimited. Adam Skarke, Robert Moorhead, Brian Davis, Mark Woodrey, Joseph French, Madelyn McFarland from Mississippi State University.

Conflicts of Interest: The authors declare no conflict of interest.

\section{References}

1. Underwood, S.G.; Steyer, G.D.; Good, B.; Chambers, D. Bay Bottom Terracing and Vegetative Planting: An Innovative Approach for Habitat and Water Quality Enhancement. In Annual Conference on Wetlands Restoration and Creation; Webb, F.J., Jr., Ed.; Hillsborough Community College: Tampa, FL, USA, 1991; pp. 164-173. 
2. Rozas, L.P.; Minello, T.J. Marsh Terracing as a Wetland Restoration Tool for Creating Fishery Habitat. Wetlands 2001, 21, 327-341. [CrossRef]

3. Turner, R.E.; Streever, B. Approaches to Coastal Wetland Restoration: Northern Gulf of Mexico; Kugler Publications: Hague, The Netherlands, 2002.

4. U.S. Fish and Wildlife Service (FWS). Available online: https://www.fws.gov/gisdownloads/R4/LouisianaESO/ (accessed on 31 July 2019).

5. Coastal Wetlands Planning, Protection and Restoration Act (CWPPRA). Available online: https://lacoast.gov/ new/Pubs/Reports/project.aspx (accessed on 31 July 2019).

6. O'Connell, J.L.; Nyman, J.A. Marsh Terraces in Coastal Louisiana Increase Marsh Edge and Densities of Waterbirds. Wetlands 2010, 30, 125-135. [CrossRef]

7. Brasher, M.G. Review of the Benefits of Marsh Terraces in the Northern Gulf of Mexico; Ducks Unlimited, Inc., Gulf Coast Joint Venture: Lafayette, LA, USA, 2015.

8. Steyer, G.D. Sabine Terracing Project Final Report; Project Number 4351089; Louisiana Department of Natural Resources, Coastal Resources Division: Baton Rouge, LA, USA, 1993.

9. Wang, W.; Liu, H.; Li, Y.; Su, J. Development and Management of Land Reclamation in China. Ocean Coast. Manag. 2014, 102, 415-425. [CrossRef]

10. Kennish, M.J. Coastal Salt Marsh Systems in the US: A Review of Anthropogenic Impacts. J. Coast. Res. 2001, 17, 731-748.

11. Nyman, J.A.; Chabreck, R.H. Managing Coastal Wetlands for Wildlife. Wildl. Tech. Man. Manag. 2012, 2, 133-156.

12. Kentula, M.E. Perspectives on Setting Success Criteria for Wetland Restoration. Ecol. Eng. 2000, 15, 199-209. [CrossRef]

13. La Peyre, M.K.; Reams, M.A.; Mendelssohn, I.A. Linking Actions to Outcomes in Wetland Management: An Overview of US State Wetland Management. Wetlands 2001, 21, 66. [CrossRef]

14. Guo, M.; Li, J.; Sheng, C.; Xu, J.; Wu, L. A Review of Wetland Remote Sensing. Sensors 2017, $17,777$. [CrossRef] [PubMed]

15. FGDC. Application of Satellite Data for Mapping and Monitoring Wetlands; Technical Report 1; Wetlands Subcomittee. Federal Geographic Data Committee (FGDC): Washington, DC, USA, 1992.

16. Penland, S.; Beall, A.D.; Britsch, L.D., III. Geologic Classification of Coastal Land Loss between 1932 and 1990 in the Mississippi River Delta Plain, Southeastern Louisiana. Gulf Coast Assoc. Geol. Soc. Trans. 2002, 52, 799-807.

17. Barras, J.A.; Beville, S.; Britsch, D.; Hartley, S.; Hawes, S.; Johnston, J.; Kemp, P.; Kinler, Q.; Martucci, A.; Porthouse, J. Historical and Projected Coastal Louisiana Land Changes: 1978-2050; USGS Open-File Report 03-334; United States Geological Survey: Lafayette, LA, USA, 2003.

18. Couvillion, B.R.; Barras, J.A.; Steyer, G.D.; Sleavin, W.; Fischer, M.; Beck, H.; Trahan, N.; Griffin, B.; Heckman, D. Land Area Change in Coastal Louisiana from 1932 to 2010; US Geological Survey Scientific Investigations Map 3164; US Geological Survey Scientific Investigations: Reston, VA, USA, 2011.

19. Oliver-Cabrera, T.; Wdowinski, S. InSAR-Based Mapping of Tidal Inundation Extent and Amplitude in Louisiana Coastal Wetlands. Remote Sens. 2016, 8, 393. [CrossRef]

20. McCarthy, J.; Gumbricht, T.; McCarthy, T.S. Ecoregion Classification in the Okavango Delta, Botswana from Multitemporal Remote Sensing. Int. J. Remote Sens. 2005, 26, 4339-4357. [CrossRef]

21. Adam, E.; Mutanga, O.; Rugege, D. Multispectral and Hyperspectral Remote Sensing for Identification and Mapping of Wetland Vegetation: A Review. Wetl. Ecol. Manag. 2010, 18, 281-296. [CrossRef]

22. Wu, Q. GIS and Remote Sensing Applications in Wetland Mapping and Monitoring; Comprenhensive Geographic Systems; Huang, B., Ed.; Elsevier: Oxford, UK, 2018; pp. 140-157.

23. Jensen, J.R. Introductory Digital Image Processing: A Remote Sensing Perspective; Prentice Hall: Englewood Cliffs, NJ, USA, 1996.

24. Klemas, V. Remote Sensing Techniques for Studying Coastal Ecosystems: An Overview. J. Coast. Res. 2010, 27, 2-17.

25. Ozesmi, S.L.; Bauer, M.E. Satellite Remote Sensing of Wetlands. Wetl. Ecol. Manag. 2002, 10, $381-402$. [CrossRef] 
26. Lu, D.; Mausel, P.; Brondizio, E.; Moran, E. Change Detection Techniques. Int. J. Remote Sens. 2004, 25, 2365-2401. [CrossRef]

27. Seif, A.; Mokarram, M. Change Detection of Gil Playa in the Northeast of Fars Province, Iran. Am. J. Sci. Res. 2012, 86, 122-130.

28. Butt, A.; Shabbir, R.; Ahmad, S.S.; Aziz, N. Land Use Change Mapping and Analysis Using Remote Sensing and GIS: A Case Study of Simly Watershed, Islamabad, Pakistan. Egypt. J. Remote Sens. Space Sci. 2015, 18, 251-259. [CrossRef]

29. Zoran, M.; Anderson, E. The Use of Multi-Temporal and Multispectral Satellite Data for Change Detection Analysis of the Romanian Black Sea Coastal Zone. J. Optoelectron. Adv. Mater. 2006, 8, 252.

30. Ahmad, F. Detection of Change in Vegetation Cover Using Multi-Spectral and Multi-Temporal Information for District Sargodha, Pakistan. Soc. Nat. 2012, 24, 557-571. [CrossRef]

31. Jensen, J.R. Digital Image Processing: A Remote Sensing Perspective, 3rd ed.; Pearson Prentice Hall: Upper Saddle River, NJ, USA, 2005.

32. Feagin, R.A.; Wu, X.B. Spatial Pattern and Edge Characteristics in Restored Terrace versus Reference Salt Marshes in Galveston Bay. Wetlands 2006, 26, 1004-1011. [CrossRef]

33. Rozas, L.P.; Minello, T.J. Using Nekton Growth as a Metric for Assessing Habitat Restoration by Marsh Terracing. Mar. Ecol. Prog. Ser. 2009, 394, 179-193. [CrossRef]

34. Loveless, J.B.; Smee, D.L. Assessing the Efficacy of Marsh Restoration via Terracing by Comparing Vegetation Density and Nekton Abundance Before and After Restoration. Gulf Mex. Sci. 2018, 34, 5. [CrossRef]

35. Ducks Unlimited. Geodatabase of Existing Marsh Terraces; Unpublished Material; Ducks Unlimited: Lafayette, LA, USA, 2015.

36. Good, B.; Peele, H.; Bourgeois, R. Aerial Growth of the Sabine Marsh Terracing Project over a Ten-Year Period; Report to the Louisiana Department of Natural Resources, Interagency Agreement; Louisiana Department of Natural Resources, Coastal Resources Division: Baton Rouge, LA, USA, 2005.

37. Castellanos, D.; Aucoin, S. Operations, Maintenance, and Monitoring Report for Little Vermilion Bay Sediment Trapping (TV-12); Louisiana Department of Natural Resources, Coastal Restoration Division: Lafayette, LA, USA, 2004.

38. Thibodeaux, C.; Guidry, M. 2009 Operations, Maintenance, and Monitoring Report for Pecan Island Terracing (ME-14); Lousiana Department of Natural Resources, Coastal Restoration Division: Lafayette, LA, USA, 2009.

39. Miller, M.; Aucoin, S. Operations, Maintenance, and Monitoring Report for the Four-Mile Canal Terracing and Sediment Trapping (TV-18); Coastal Protection and Restoration Authority of Louisiana: Lafayette, LA, USA, 2011.

40. USDA. National Agricultural Imagery Program (NAIP). Geospatial Data Gateway. Available online: https://datagateway.nrcs.usda.gov/ (accessed on 1 June 2018).

41. Jankowski, K.L.; Törnqvist, T.E.; Fernandes, A.M. Vulnerability of Louisiana's Coastal Wetlands to Present-Day Rates of Relative Sea-Level Rise. Nat. Commun. 2017, 8, 14792. [CrossRef] [PubMed]

42. USDA. Farm Service Agency. NAIP Imagery. Available online: https://www.fsa.usda.gov/programs-andservices/aerial-photography/imagery-programs/naip-imagery/ (accessed on 1 June 2018).

43. Brasher, M.G.; Ducks Unlimited, Inc., Gulf Coast Joint Venture, Lafayette, LA, USA. Personal communication, 2018.

44. Simons, K.L. A Comparison of Two Common Classification Procedures for Economical Urban Land Cover Mapping Using NAIP Imagery. Master's Thesis, Brigham Young University, Provo, UT, USA, 2009.

45. Coastal Protection and Restoration Authority of Louisiana (CPRA). Coastwide Reference Monitoring System-Wetlands Monitoring Data. Available online: http://cims.coastal.louisiana.gov (accessed on 16 June 2018).

46. Day, R.H.; Holz, R.K.; Day, J.W. An Inventory of Wetland Impoundments in the Coastal Zone of Louisiana, USA: Historical Trends. Environ. Manag. 1990, 14, 229-240. [CrossRef]

47. Wicker, K.M.; Roberts, D.; Davis, D. Rockefeller State Wildlife Refuge and Game Preserve: Evaluation of Wetland Management Techniques; Louisiana Department of Natural Resources, Coastal Management Section: Baton Rouge, LA, USA, 1983.

48. Cowan, J.H.; Turner, R.E.; Cahoon, D.R. Marsh Management Plans in Practice: Do They Work in Coastal Louisiana, USA? Environ. Manag. 1988, 12, 37-53. [CrossRef] 
49. Bolduc, F.; Afton, A.D. Sediments in Marsh Ponds of the Gulf Coast Chenier Plain: Effects of Structural Marsh Management and Salinity. Wetl. Ecol. Manag. 2005, 13, 395-404. [CrossRef]

50. ESRI. ArcGIS Desktop; Environmental Systems Research Institute: Redlands, CA, USA, 2011.

51. Hexagon Geospatial. ERDAS IMAGINE; Erdas Inc.: Madison, AL, USA, 2016.

52. Hammond, M. PythonWin IDE amd GUI; Python Software Foundation: Wilmington, DE, USA, 2010.

53. Congalton, R.G. A Review of Assessing the Accuracy of Classifications of Remotely Sensed Data. Remote Sens. Environ. 1991, 37, 35-46. [CrossRef]

54. Congalton, R.G.; Green, K. Assessing the Accuracy of Remotely Sensed Data: Principles and Practices; CRC Press: Boca Raton, FL, USA, 2002.

55. Google Earth. Available online: https://www.google.com/earth/ (accessed on 1 December 2019).

56. Mohammed, J. Land Use and Cover Change Assessment Using Remote Sensing and GIS: Dohuk City, Kurdistan, Iraq (1998-2011). Int. J. Geomat. Geosci. 2013, 3, 552-569.

57. Ratnaparkhi, N.S.; Nagne, A.D.; Gawali, B. A Land Use Land Cover Classification System Using Remote Sensing Data. Changes 2014, 7, 8.

58. Hurlbert, S.H. Pseudoreplication and the Design of Ecological Field Experiments. Ecol. Monogr. 1984, 54, 187-211. [CrossRef]

59. González, J.L.; Tornqvist, T.E. Coastal Louisiana in Crisis: Subsidence or Sea Level Rise? Eos Trans. Am. Geophys. Union 2006, 87, 493-498.

60. Yuill, B.; Lavoie, D.; Reed, D.J. Understanding Subsidence Processes in Coastal Louisiana. J. Coast. Res. 2009, 23-36. [CrossRef]

61. Morton, R.A.; Bernier, J.C. Recent Subsidence-Rate Reductions in the Mississippi Delta and Their Geological Implications. J. Coast. Res. 2010, 26, 555-561. [CrossRef]

62. Owen, D.E. Geology of the Chenier Plain of Cameron Parish, Southwestern Louisiana. Geol. Soc. Am. Field Guide 2008, 14, 27-38.

63. Hijma, M.P.; Shen, Z.; Törnqvist, T.E.; Mauz, B. Late Holocene Evolution of a Coupled, Mud-Dominated Delta Plain-Chenier Plain System, Coastal Louisiana, USA. Earth Surf. Dyn. 2017, 5, 689. [CrossRef]

64. Penland, S.; Ramsey, K.E. Relative Sea-Level Rise in Louisiana and the Gulf of Mexico: 1908-1988. J. Coast. Res. 1990, 6, 323-342.

65. Day, J.W.; Boesch, D.F.; Clairain, E.J.; Kemp, G.P.; Laska, S.B.; Mitsch, W.J.; Orth, K.; Mashriqui, H.; Reed, D.J.; Shabman, L. Restoration of the Mississippi Delta: Lessons from Hurricanes Katrina and Rita. Science 2007, 315, 1679-1684. [CrossRef]

66. Howes, N.C.; FitzGerald, D.M.; Hughes, Z.J.; Georgiou, I.Y.; Kulp, M.A.; Miner, M.D.; Smith, J.M.; Barras, J.A. Hurricane-Induced Failure of Low Salinity Wetlands. Proc. Natl. Acad. Sci. USA 2010, 107, 14014-14019. [CrossRef]

67. Day, J.W.; Britsch, L.D.; Hawes, S.R.; Shaffer, G.P.; Reed, D.J.; Cahoon, D. Pattern and Process of Land Loss in the Mississippi Delta: A Spatial and Temporal Analysis of Wetland Habitat Change. Estuaries 2000, 23, 425-438. [CrossRef]

68. Reed, D.J.; De Luca, N.; Foote, A.L. Effect of Hydrologic Management on Marsh Surface Sediment Deposition in Coastal Louisiana. Estuaries 1997, 20, 301-311. [CrossRef]

69. Cahoon, D.R. Recent Accretion in Two Managed Marsh Impoundments in Coastal Louisiana. Ecol. Appl. 1994, 4, 166-176. [CrossRef]

70. Bryant, J.C.; Chabreck, R.H. Effects of Impoundment on Vertical Accretion of Coastal Marsh. Estuaries 1998, 21, 416-422. [CrossRef]

71. Hymel, M.K.; Breaux, K.A. 2012 Operations, Maintenance, and Monitoring Report for Delta Management at Fort St. Philip; Coastal Protection and Restoration Authority of Louisiana: New Orleans, LA, USA, 2012.

72. Coastal Protection and Restoration (CPRA). Louisiana's Comprehensive Master Plan. for a Sustainable Coast; Coastal Protection Restoration Authority, Integrated Planning Team: Baton Rouge, LA, USA, 2017.

73. Morton, R.A.; Barras, J.A. Hurricane Impacts on Coastal Wetlands: A Half-Century Record of Storm-Generated Features from Southern Louisiana. J. Coast. Res. 2011, 27, 27-43. [CrossRef]

74. Barras, J.A.; Bernier, J.C.; Morton, R.A. Land Area Change in Coastal Louisiana, a Multidecadal Perspective (from 1956 to 2006); US Department of the Interior, US Geological Survey Scientific Investigations: Reston, VA, USA, 2008. Available online: https://pubs.usgs.gov/sim/3019/ (accessed on 4 June 2019). 
75. Steyer, G.D.; Cretini, K.F.; Piazza, S.C.; Sharp, L.A.; Snedden, G.A.; Sapkota, S. Hurricane Influences on Vegetation Community Change in Coastal Louisiana; US Geological Survey: Reston, VA, USA, 2010.

76. Tweel, A.W.; Turner, R.E. Landscape-Scale Analysis of Wetland Sediment Deposition from Four Tropical Cyclone Events. PLoS ONE 2012, 7, e50528. [CrossRef] [PubMed]

77. Draut, A.E.; Kineke, G.C.; Huh, O.K.; Grymes, J.M., III; Westphal, K.A.; Moeller, C.C. Coastal Mudflat Accretion under Energetic Conditions, Louisiana Chenier-Plain Coast, USA. Mar. Geol. 2005, 214, $27-47$. [CrossRef]

(C) 2020 by the authors. Licensee MDPI, Basel, Switzerland. This article is an open access article distributed under the terms and conditions of the Creative Commons Attribution (CC BY) license (http://creativecommons.org/licenses/by/4.0/). 